\title{
Analisis Produktivitas PT. Perkebunan Nusantara V (PKS) Sei Galuh Dengan Menggunakan Metode American Productivity Center (APC)
}

\author{
Isum Kusumanto ${ }^{1}$, Septend Hadyguna Hermanto ${ }^{2}$ \\ 1,2 Jurusan Teknik Industri, Fakultas Sains dan Teknologi, UIN Sultan Syarif Kasim Riau \\ Jl. HR. Soebrantas No. 155 Simpang Baru, Panam, Pekanbaru, 28293 \\ Email: ismu_uin@yahoo.co.id, septendhadyguna@yahoo.com
}

\begin{abstract}
ABSTRAK
Data statistik perusahaan menunjukan kenaikan bahan baku berupa tandan buah segar yang diolah tidak diikuti dengan peningkatan hasil produksi CPO (crude palm oil) dan inti, hal ini menunjukan terjadinya penurunan produktivitas perusahaan yang akan berdampak menurunnya pendapatan bersih perusahaan. Tujuan dari penelitian ini adalah untuk mengetahui tingkat perkembangan indeks produktivitas dan indeks profitabilitas perusahaan dengan menggunakan metode APC (American Productivity Center). Hasil dari pengukuran produktivitas selama tahun 2014 adalah indeks produktivitas perusahaan mengalami penurunan, hal ini disebabkan oleh jumlah input-input yang digunakan dalam proses produksi masih jauh lebih tinggi dibandingkan dengan hasil produksi, untuk itu perusahaan perlu mengoptimalkan proses produksi agar peningkatan TBS (tandan buah segar) yang diolah berbanding lurus dan positif dengan hasil produksi.
\end{abstract}

Kata Kunci: American Productivity Center, Indeks Perbaikan Harga, Indeks Produktivitas, Indeks Profitbilitas, dan Produktivitas

\section{Pendahuluan}

Dewasa ini intensitas persaingan bisnis terus mengalami peningkatan, khususnya perusahaan yang bergerak di bidang pengolahan kelapa sawit. Data dari badan pusat statistik menunjukan jumlah pabrik kelapa sawit yang terdapat di Indonesia terus mengalami peningkatan, dimana pada tahun 2000 tercatat jumlah pabrik kelapa sawit di Indonesia adalah sebanyak 693 pabrik dan pada tahun 2014 tercatat jumlah pabrik kelapa sawit di Indonesia sebanyak 1601 pabrik.

Hal ini memacu dunia usaha untuk lebih peduli terhadap strategi yang membawa kepada dua hal, yaitu keunggulan dan nilai. Perusahaan terus berupaya untuk merumuskan dan menyempurnakan strategi-strategi bisnis mereka dalam rangka memenangkan persaingan (the winning strategy). Untuk mendukung efektifitas strategi tersebut maka manajemen perusahaan perlu mengukur kinerja bisnis mereka (susanto, 2006 dalam Susanti dkk., 2008). Salah satu cara untuk menilai kinerja perusahaan adalah dengan mengukur produktivitas perusahaan (Nopiandi, 2012). Hasil dari pengukuran produktivitas dapat dijadikan informasi dalam pengambilan keputusan untuk mengatasi faktor-faktor penyebab penurunan produktivitas.

Menurut dewan produktivitas nasional RI (Republik Indonesia) produksi dan produktivitas merupakan dua pengertian yang berbeda. Peningkatan produksi menunjukan pertambahan jumlah hasil yang dicapai, sedangkan peningkatan produktivitas mengandung pengertian pertambahan hasil dan perbaikan cara produksi. Peningkatan produksi tidak selalu disebabkan oleh peningkatan produktivitas, karena produksi dapat meningkat walaupun produktivitas tetap atau menurun.

Produktivitas merupakan salah satu indikator penentu bagi perusahaan untuk dapat terus membuktikan eksistensinya di tengah persaingan dengan perusahaan kompetitor. Untuk itu perusahaan dituntut untuk dapat terus meningkatkan produktivitasnya agar dapat memenangkan persaingan pasar (Nasution, 2006). Kendala yang dihadapi perusahaan dalam meningkatkan produktivitas dilantai produksi umumnya dipengaruhi oleh faktor penggunaan sumber daya yang tidak tepat selama kegiatan produksi berlangsung (Avianda dkk., 2015).

Penelitian dilakukan di PT Perkebunan Nusantara V Sei Galuh, perusahaan ini bergerak di bidang pengolahan kelapa sawit menjadi CPO (Crude Palm Oil) dan inti sawit. Perusahaan ini memiliki moto "Jurney to Excellence" (menuju keunggulan) dan salah satu misi perusahaan adalah "mengelola agro industri kelapa sawit secara efisien bersama mitra untuk kepentingan stakeholder", namun dalam pengukuran tingkat pencapaiannya perusahaan ini masih berpatokan terhadap target produksi. Hal ini menyebabkan perusahaan tidak dapat melihat sejauh mana perkembangan efektivitas dan efisiensi perusahaan dalam melakukan proses produksi, selain itu terdapat beberapa pemborosan yang terjadi dalam proses 
produksi seperti pemborosan penggunaan air dan pemborosan penggunaan listrik, yang luput dari perhatian perusahaan, hal ini tentunya berdampak tidak maksimalnya pendapatan total perusahaan.

Data statistik pengolahan di PT. Perkebunan Nusantara V Sei Galuh pada tahun 2015 menunjukan terjadi peningkatan jumlah tandan buah segar yang diolah dari awal bulan sampai dengan akhir bulan. Berikut merupakan garafik yang menunjukan kenaikan jumlah tandan buah segar yang diolah selama tahun 2015 :

\section{TBS OLAH 2015}

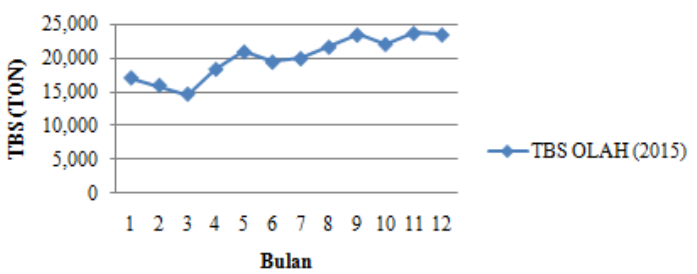

Gambar 1. Grafik jumlah tandan buah segar yang diolah selama tahun 2015

Dari data statistik tersebut tandan buah segar yang diolah mengalami peningkatan, namun dari sisi produktivitas cpo (crude palm oil) dan inti yang dihasilkan mengalami penurunan. Berikut merupakan grafik yang menunjukan penurunan produktivitas cpo (crude palm oil) dan inti yang dihasilkan selama tahun 2015 :

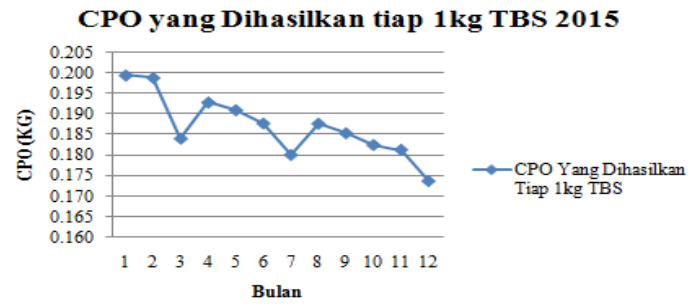

Gambar 2. Grafik cpo yang dihasilkan tiap $1 \mathrm{~kg}$ tbs

Inti yang Dihasilkan tiap $1 \mathrm{~kg}$ TBS 2015

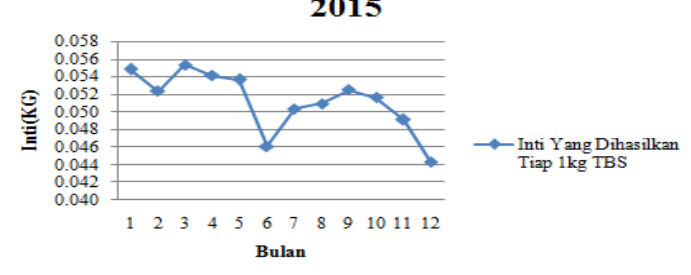

Gambar 3. Grafik inti ang dihasilkan tiap $1 \mathrm{~kg}$ tbs

Grafik diatas menunjukan adanya permasalahan di perushaan dimana kenaikan jumlah tandan buah segar yang diolah tidak diikuti dengan peningkatan hasil produksi CPO (crude palm oil) dan inti, hal ini menunjukan terjadinya penurunan produktivitas pada bagian produksi di PT. Perkebunan Nusantara V Sei Galuh yang akan berdampak pada menurunnya pendapatan bersih perusahaan, selain itu dalam proses produksi juga terdapat peningkatan konsumsi air dan listrik, peningkatan ini juga menyebabkan biaya-biaya produksi mengalami peningkatan dan pada akhirnya pendapatan bersih yang diperoleh perusahaan tidak maksimal. Untuk itu diperlukan suatu ukuran yang dapat menggambarkan keadaan internal perusahaan terutama yang berkaitan dengan efisiensi dan efektivitas penggunaan sumber daya dalam menghasilkan cpo (crude palm oil) dan inti. Sehingga kedepannya diharapkan informasi mengenai tingkat produktivitas perusahaan dapat dijadikan dasar dalam evaluasi serta penetapan strategi perusahaan.

Berdasarkah permasalahan diatas, maka rumusan masalah dari penilitian ini yaitu, "melakukan analisis produktivitas pada bagian produksi di PT Perkebunan Nusantara V Sei Galuh dengan menggunakan metode The American Productivity Center".

\section{Tinjauan Pustaka}

\section{Definisi Produktivitas}

Jika membicarakan masalah produktivitas munculah suatu situasi yang paradoksial (bertentangan), karena belum ada kesepakatan umum tentang maksud pengertian produktivitas serta kriterianya dalam mengukur petunjuk-petunjuk produktivitas. Dan tak ada konsepsi, metode penerapan maupun cara pengukuran yang bebas kritik (Sinungan, 2005).

Produktivitas juga diartikan sebagai tingkatan efisiensi dalam memproduksi barang-barang atau jasajasa: "produktivitas mengutarakan cara pemanfaaatan secara baik terhadap sumber-sumber dalam memproduksi barang-barang" (Sinungan, 2005).

L. Greenberg mendefinisikan produktivitas sebagai perbandingan antara totalitas pengeluaran pada waktu tertentu dibagi totalitas masukan selama periode tersebut (Sinungan, 2005).

Produktivitas didefinisikan sebagai hubungan antara input dan output suatu sistem produksi. Hubungan ini sering lebih umum dinyatakan sebagai rasio output dibagi input. Jika lebih banyak output yang dihasilkan dengan input yang sama, maka disebut terjadi peningkatan produktivitas. Begitu juga kalau input yang lebih rendah dapat menghasilkan output yang tetap, maka produktivitas dikatakan meningkat (Nasution, 2006).

Produktivitas merupakan suatu istilah yang seringkali disama artikan dengan kata produksi. Antara produktivitas dan produksi mempunyai arti yang berbeda karena pada saat produksi tinggi belum tentu produktivitasnya juga tinggi, bisa jadi produktivitasnya malah semakin rendah. Tinggi rendahnya suatu produktivitas berkaitan dengan efisiensi dari sumber daya (input) dalam menghasilkan suatu produk atau jasa (output) (Sinungan, 2005).

Menurut Griffin (2004) dalam Sibarani (2012) produktivitas (productivity) adalah ukuran efisiensi 
ekonomis yang mengikhtisiarkan nilai dari output relatif terhadap nilai dari input yang dipakai untuk menciptakannya.

Produktivitas adalah suatu pendekatan interdisipliner untuk menentukan tujuan yang efektif, pembuatan rencana, aplikasi penggunaan cara yang produktivitas untuk menggunakan sumber-sumber secara efisien, dan tetap menjaga adanya kualitas yang tinggi. Produktivitas mengikutsertakan pendayagunaan secara terpadu sumberdaya manusia dan keterampilan, barang modal, teknologi, manajemen, informasi, energy, dan sumber-sumber lain menuju kepada pengembangan dan peningkatan standar.(Sinungan, 2005).

Gasperz (2000) dalam Eko (2009) menyatakan hubungan antara profitabilitas dan produktivitas. "Jika perusahaan memiliki tingkat produksi yang tinggi sedangkan tingkat produktivitasnya rendah, maka yang akan terjadi adalah tingkat profitabilitas tidak akan berlanjut dalam jangka panjang, dalam jangka panjang produktivitas yang rendah akan menggerogoti perusahaan".

Profitabilitas merupakan konsep financial yang diperoleh dengan mengurangi nilai penjualan dengan nilai biaya. Karena dinyatakan dalam "nilai" (rupiah) maka nilai profitabilitas sangat dipengaruhi oleh variabel harga. Pada umumnya faktor yang menentukan tingkat harga berada diluar control perusahaan. misalnya, kalau dalam pasar barang terjadi perubahan permintaan terhadap suatu barang tertentu maka perusahaan yang membuat barang tersebut cenderung mengalami laba (windfall profit), kenaikan laba disebabkan faktor eksternal perusahaan yang tidak dapat dikuasai oleh perusahaan sedangkan konsep produktivitas memfokuskan pada hubungan output dan input yang dipakai. Berdasarkan Piagam Produktivitas Oslo tahun 1994, antara lain (Sinungan, 2005):

1. Produktivitas adalah konsep universal, dimaksudkan untuk menyediakan semakin banyak barang dan jasa untuk kebutuhan semakin banyak orang dengan menggunakan sumber daya yang sedikit mungkin. Produktivitas didasarkan pada pendekatan multi disiplin yang secara efektif merumuskan tujuan, rencana, pengembangan, dan pelaksanaan cara-cara produktif, dengan menggunakan sumber daya secara efsien namun tetap mempertahankan kualitas.

2. Produktivitas secara terpadu melibatkan semua usaha manusia dengan menggunakan keterampilan, modal, teknologi, manajemen, informasi, energy, dan sumber-sumber daya lainnya, untuk perbaikan mutu kehidupan yang baik bagi seluruh manusia, melalui pendekatan konsep produktivitas secara total.

3. Peningkatan produktivitas dapat dilihat dalam tiga bentuk :

a. Jumlah keluaran (output) dalam mencapai tujuan meningkat dengan menggunakan sumberdaya yang sama.

b. Jumlah keluaran (output) dalam mencapai tujuan sama atau meningkat dicapai dengan menggunakan sumber daya (input) yang lebih sedikit. c. Jumlah keluaran (output) dalam mencapai tujuan jauh lebih besar diperoleh dengan pertambahan sumber daya (input) yang relative lebih kecil.

4. Sumber daya manusia memegang peranan yang utama dalam proses peningkatan produktivitas, karena alat produksi dan teknologi pada hakekatnya merupakan hasil karya manusia.

\section{Konsep Produktivitas}

Istilah produktivitas pertama kali muncul tahun 1776 dalam naskah Qusney dari Perancis, namun filosofi dan keberadaan produktivitas sudah ada sejak awal peradaban manusia di muka bumi ini. Makna dari produktivitas adalah suatu upaya atau keinginan manusia untuk selalu meningkatkan kualitas hidupnya dengan menggunakan sumber daya sekecil mungkin. Penerapan aliran produksi yang searah dan lancer maupun penanganan beberapa proses sekaligus sangat berguna bagi penyempurnaan produktivitas kerja, kualitas, waktu penyerahan produksi, tingkat persediaan, dan pemanfaatan ruang (Suzaki 1987, dalam Agustina dkk, 2011).

Produktivitas tidak sama dengan produksi tetapi produksi, performa kualitas, hasil-hasil merupakan komponen dari usaha produktivitas. Dengan demikian produktivitas merupakan kombinasi dari efektivitas dengan efisien (Gasperz 2000, dalam Agustina dkk 2011).

Untuk menerapkan suatu konsep, adakalanya lebih efektif kalau dimulai dengan mebahas hal-hal yang justru tidak termasuk dalam konsep tersebut. Jadi paragraph ini akan membahas beberapa pengertian yang bukan termasuk konsep produktivitas (Sinungan, 2005).

Pertama, produktivitas bukan "produksi". Pengertian produksi selalu berorientasi ke "output" saja yang mempunyai unit satuan berdimensi satu (seperti : $\mathrm{kg}$ atau ton). Pertanyaan yang sering terkait dengan upaya peningkatan produksi adalah HOW MUCH ?, sedangkan pertanyaan yang terkait dengan upaya peningkatan produktivitas adalah HOW WELL ?. Hal ini disebabkan, dalam pengertian produktivitas perhatian bukan hanya tertuju pada output saja melainkan juga pada input. Unit satuan yang dipakai dalam produktivitas adalah berdimensi dua (seperti: ton per hektar) (Sinungan, 2005).

Kedua, produktivitas bukan "efisiensi". Pengertian efisiensi selalu berorientasi ke input. Tindakan yang efisien berarti menghemat penggunaan input atau dapat mendekati suatu standar tertentu (Sinungan, 2005).

Ketiga, produktivitas bukan "pengukuran kerja" (work measurement). Konsep pengukuran kerja bertujuan untuk mengetahui jumlah kerja yang dibutuhkan oleh seorang pekerja dalam menyelesaikan suatu tugas yang sesuai dengan suatu standar tertentu (Sinungan, 2005).

Keempat, produktivitas bukan "profitabilitas". Konsep profitabilitas merupakan konsep financial yang diperoleh dengan mengurangi nilai penjualan dengan biaya-biaya. Karena dinyatakan dalam nilai (rupiah) maka nilai profitabilitas sangat dipengaruhi oleh variabelvariabel harga (baik harga input maupun harga output). Pada umumnya faktor-faktor yang mempengaruhi tingkat 
harga berada di luar control perusahaan. misalnya jika dalam pasar barang terjadi perubahan permintaan terhadap suatu barang tertentu, maka perusahaan yang membuat barang tadi cenderung akan mengalami kenaikan laba. Jadi kenaikan laba tadi disebabkan oleh faktor eksternal yang tidak dapat dikuasai oleh perusahaan yang bersangkutan. Sedangkan konsep produktivitas tidak banyak dipengaruhi oleh fluktuasi harga karena memfokuskan pada hubungan output dan input yang dipakai. Suatu perusahaan disebut produktif kalau dapat mempertahankan tingkat output dengan input yang semakin berkurang atau meningkat output tidak menambah input. Jadi masalah output-input berada dalam kontrol perusahaan. dalam situasi pasar barang yang disebutkan di atas dapat saja suatu perusahaan yang tidak produktif tetap akan mengalami laba positif. Tetapi jika pasar berubah menjadi "lesu" maka pada umunya perusahaan yang tidak produktif akan mengalami kerugian yang besar. Sebaliknya perusahaan yang produktif meskipun pasar lesu tetap dapat mencapai laba positif(Sinungan, 2005).

Setelah pembahasan di atas maka kini tiba saatnya menjelaskan pengertian produktivitas. Dari uraian terdahulu dapat diketahui bahwa konsep produktivitas adalah hubungan antara output dan input. Jadi orientasinya bukan hanya tertuju pada output atau input melainkan kepada keduanya. Oleh karena itu konsep produktivitas "lebih luas" dari konsep-konsep yang berorientasi pada satu segi saja (seperti efisiensi, produksi, dan efektivitas). Jadi dalam kegiatan pengukuran produktivitas perlu diukur baik output maupun input. Hubungan antara output dan input biasanya dinyatakan dalam rasio atau indeks (perbandingan rasio dengan rasio) (Sinungan, 2005).

\section{Bagaimana Mengukur Produktivitas}

Di bagian muka telah dikatakan bahwa produktivitas adalah konsep yang menghubungkan output dan input. Dalam pengukuran produktivitas dikenal dua pendekatan:

1. Pendekatan produktivitas total atau faktor ganda yaitu output dihadapkan dengan seluruh input yang dipakai $(5 \mathrm{M}+\mathrm{E}+\mathrm{I})$.

2. Pendekatan parsial atau faktor tunggal yaitu output dihadapkan dengan satu input saja (seperti produktivitas tenaga kerja atau produktivitas modal).

Dalam pengukuran produktivitas dikenal 4 strata yaitu:

1. Makro (seluruh ekonomi suatu Negara)

2. Sektoral (pertanian atau industri sepatu)

3. Perusahaan (pabrik gula atau hotel)

4. Individu

Di strata perusahaan jika digunakan pendekatan produktivitas parsial maka dapat diukur rasio atau indeks produktivitas tentang tenaga kerja, modal, organisasi, penjualan, produksi, dan produk (Sinungan, 2005).

Karena produktivitas menyatakan rasio antara output dan input maka dalam pekerjaan pengukuran produktivitas terlebih dahulu harus disusun definisi kerja dan kemudian cara mengukur baik output maupun input.
Secara garis besar setiap variabel dapat dinyatakan dalam satuan fisik (berat, volume, hari, jam, panjang) atau satuan nilai rupiah (nilai produksi, nilai tambah). Kemudian produktivitas dalam satuan fisik dapat dinyatakan dalam konsep "stok". Sedangkan kalau dinyatakan dalam bentuk: $\mathrm{X}$ ton per jam kerja adalah konsep "arus" (Sinungan, 2005).

Dalam kenyataan ada dua jenis perusahaan yaitu penghasil barang dan jasa. Dalam kasus perusahaa penghasil barang, mengukur output lebih mudah dibandingkan dengan mengukur input. Hal ini disebabkan karena jenis input yang digunakan relatif lebih banyak jenisnya. Sebaliknya dalam kasus perusahaan penghasil jasa, output lebih sulit diukur dibandingkan dengan input (Sinungan, 2005).

\section{Mana yang Lebih Penting Produktivitas atau Profitabilitas}

Di kalangan dunia usaha sering dipertanyakan tentang manfaat dari suatu upaya peningkatan produktivitas. Ada asumsi bahwa peningkatan produktivitas mempunyai implikasi terhadap meningkatnya biaya. Dalam dunia usaha ada semacam anggapan, bahwa yang lebih penting adalah laba dan bukan produktivitas. Dunia usaha baru akan tertarik terhadap produktivitas apabila melalui cara tersebut akan meningkatkan laba. Hubungan antara tingkat produktivitas dengan tingkat laba memang tidak selalu berjalan atas korelasi searah (positif). Dapat juga arahnya bertolak belakang. Faktor yang menyebabkan terjadinya arah yang sejalan atau berbeda adalah faktor pricerecovery (Sinungan, 2005).

Pengertian price-recovery adalah suatu kebijaksanaan devaluasi cenderung akan meningkatkan harga barang impor. Kalau harga masukan meningkat ada kecendrungan suatu perusahaan untuk menaikan harga keluarannya. Kalau perusahaan itu dengan cepat dapat menggeserkan kenaikan harga masukan ke harga keluaran maka dikatakan perusahaan tersebut memiliki price-recovery yang tinggi. Jadi meskipun perusahaan meiliki tingkat produktivitas yang relatif tinggi tetapi memiliki price-recovery yang rendah maka perusahaan tidak dapat mempertahankan laba pada tingkat sebelum devaluasi (Sinungan, 2005).

\section{Syarat Pengukuran Produktivitas}

Syarat utama yang harus diikuti oleh setiap organisasi atau perusahaan dalam melakukan pengukuran produktivitas yang benar, yaitu (Bain, 1982 dalam Eko, 2009) :

1. Keabsahan (validity)

Keabsahan (validity) yaitu ukuran yang dapat menggambarkan perubahan tingkat produktivitas yang sebenarnya secara tepat.

2. Kelengkapan (completeness)

Keikutsertaan seluruh faktor yang berpengaruh baik dari segi masukan maupun keluaran akan memberikan ketelitian yang tinggi pada hasil pengukuran produktivitas.

3. Dapat dibandingkan (comparability) 
Syarat utama dalam pengukuran tingkat produktivitas adalah ketersediaan data dan data yang tersedia harus dapat dibandingkan. Perbandingan dilakukan terhadap hasil pengukuran produktivitas di dalam periode yang berbeda.

4. Ketermasukan (inclusiveness)

Pengukuran tingkat produktivitas menyatakan banyak kegiatan dalam fumgsi-fungsi organisasi perusahaan.

5. Efektivitas ongkos (cost effectiveness)

Disamping manfaat yang diperoleh, pengukuran tingkat produktivitas juga memerlukan ongkos diluar ongkos produksi. Agar ongkos yang dikeluarkan untuk kegiatan pengukuran tingkat produktivitas tidak mengurangi nilai manfaat yang dihasilkan, perlu dilakukan analisis rugi dalam pengukuran ini.

6. Tepat waktu (timeliness)

Agar informasi yang diperoleh dari pengukuran produktivitas tepat guna maka periode waktu pengukuran produktivitas harus disesuaikan dengan kebutuhan perusahaan.

\section{Pengukuran Produktivitas Model American Productivity Center (APC)}

Pusat produktivitas Amerika (The American Productivity Center - APC)

Mengemukakan ukuran produktivitas sebagai berikut (Nasution, 2007):

$$
\begin{aligned}
& \text { Profitabilitas }=\frac{\text { Hasil penjualan }}{\text { Biaya-Biaya }} \\
& =\frac{\text { Bayak output } \times \text { harga per unit }}{\text { Banyak input } \times \text { harga per unit }} \\
& =\frac{\text { Banyak output }}{\text { Banyak input }} \times \frac{\text { Harga }}{\text { Biaya }} \\
& =(\text { Produktivitas }) \times(\text { Faktor perbaikan harga })
\end{aligned}
$$

Dari ukuran produktivitas yang dikemukakan APC tampak bahwa ada hubungan profitabilitas dengan produktivitas dan faktor perbaikan harga. Rasio produktivitas memberikan suatu indikasi penggunaan sumber-sumber dalam menghasilkan output perusahaan (Nasution, 2007).

Model APC untuk pengukuran produktivitas pada tingkat perusahaan ditunjukan dalam gambar berikut:

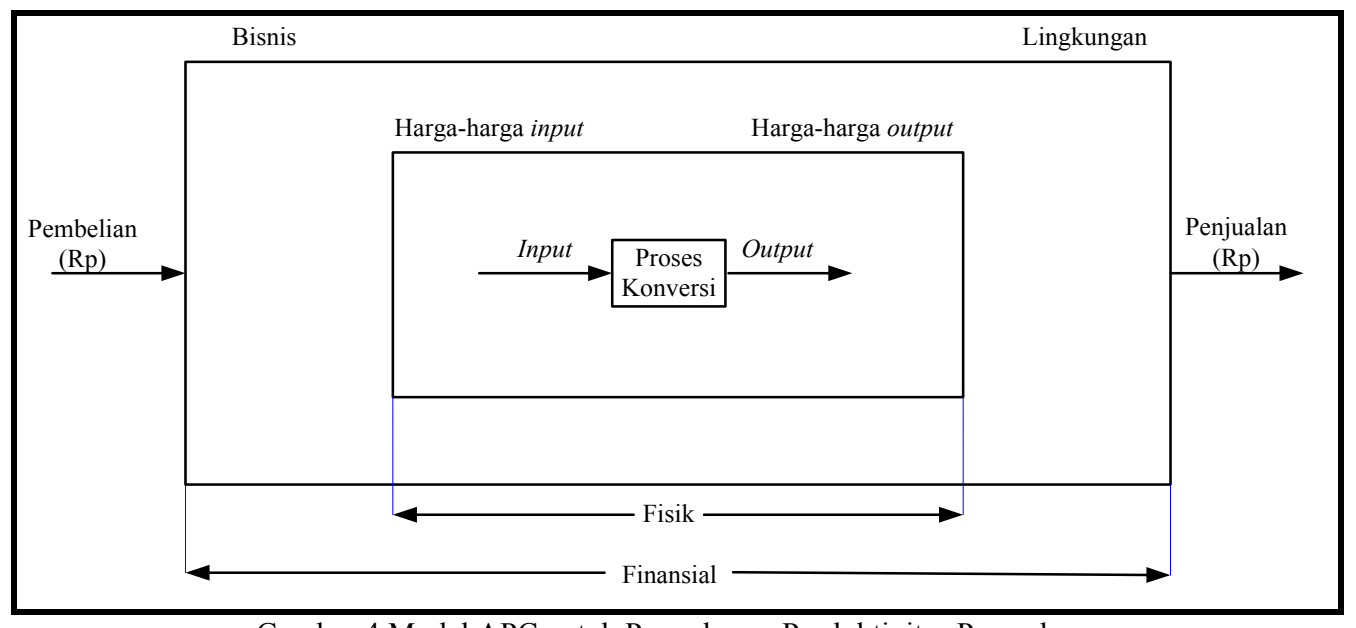

Gambar 4 Model APC untuk Pengukuran Produktivitas Perusahaan

(Sumber : Nasution, 2007)

Dalam model APC, kuantitas output dan input setiap tahun digandakan dengan harga-harga tahun dasar untuk menghasilkan indeks produktivitas. Harga-harga dan biaya per unit setiap tahun digandakan dengan kuantitas output dan input pada tahun tertentu sehingga akan menghasilkan indeks perbaikan harga di tahun itu (Nasution, 2007).

Indeks perbaikan harga menunjukan perubahan dalam biaya input terhadap harga output perusahaan. Dalam model APC, biaya per unit tenaga kerja, material, dan energy dihitung atau ditentukan secara langsung, sedangkan perhitungan input modal ditentukan berdasarkan depresi total ditambah keuntungan relatif terhadap harta total (harta tetap + modal kerja) yang dipergunakan. Dengan demikian input modal untuk suatu periode tertentu sama dengan depresiasi ditambah (ROA periode dasar) dikalikan harta sekarang yang dipergunakan.

Adapun kelebihan pengukuran produktivitas dengan metode APC (American Productivity Center) adalah sebagai berikut :

1. Model pengukuran dengan menggunakan angka indeks lebih bisa digunakan untuk membandingkan tingkat produktivitas antar periode yang satu dengan periode yang lainnya.

2. Pada model APC (American Productivity Center) dapat menentukan tingkat produktivitas, tingkat profitabilitas, dan faktor perbaikan harga perusahaan.

3. Pada model APC (American Productivity Center) dapat memberikan informasi yang lebih 
jelas dan komprehensif tentang sumber-sumber peningkatan profitabilitas perusahaan, apakah berasal dari peningkatan produktivitas, faktor perbaikan harga produk di pasar global, atau produktivitas sekaligus faktor perbaikan harga produk di pasar global.

4. Pada model APC (American Productivity Center) dapat dibandingkan besarnya angka indeks antar fungsi produksi dalam satu periode maupun antar periode, sehingga kita dapat mengetahui fungsi produksi dan produktivitasnya paling rendah serta fungsi produksi yang paling berpengaruh, sehingga dapat dijadikan pedoman untuk merencanakan peningkatan produktivitas perusahaan.

Metode APC (American Productivity Center) merupakan metode yang berasal dari pusat produktivitas Amerika, dimana metode ini dapat diterapkan pada perusahaan yang bergerak dibidang manufaktur bukan perusahaan bergerak dibidang jasa, karena dalam metode APC (American Productivity Center) perhitungannya menggunakan data input dan output. Ukuran produktivitas dan profitabilitas digunakan secara bersama sepanjang waktu, dimana ukuran profitabilitas digunakan untuk memantau keadaan pasar (masalah eksternal) terutama yang berkaitan dengan efisiensi penggunaan sumberdaya dalam menghasilkan output dari perusahaan (Gaspersz, 1998).

\section{Perhitungan Angka Indeks Produktivitas}

Angka indeks merupakan suatu besaran yang menunjukan variasi perubahan dalam waktu atau ruang mengenai suatu hal tertentu. Indeks produktivitas adalah angka produktivitas yang dibandingkan dengan angka tahun dasar untuk mengetahui perubahan atau turun naiknya produktivitas (Eka, 2012).

Pada model APC perhitungan angka indeks yang produktivitas dilakukan dengan harga konstan. Angka indeks yang akan digunakan dalam pengukuran produktivitas ini terdiri dari lima indeks produktivitas utama, namun sebelumnya dilakukan pengukuran terhadap enam indeks pendukung yang dapat mendukung dalam analisis selanjutnya, adapun indeks tersebut antara lain (Eka, 2012) :
a. Indeks output $(\mathrm{O})=\frac{\mathrm{On}}{\mathrm{Oi}}$
b. Indeks input tenaga kerja $(\mathrm{L})=\frac{\mathrm{Ln}}{\mathrm{Li}} \cdot 6$
c. Indeks input material $(\mathrm{M})=\frac{\mathrm{Mn}}{\mathrm{Mi}} 2.7$
d. Indeks input energi $(\mathrm{E})=\frac{\mathrm{En}}{\mathrm{Ei}} 2.8$
e. Indeks input modal $(\mathrm{K})=\frac{\mathrm{Kn}}{\mathrm{Ki}} 2.9$
f. Indeks input total $(\mathrm{I})=\frac{\mathrm{In}}{\mathrm{Ii}} 2.10$

Keterangan :

$$
\begin{array}{ll}
\mathrm{O} & =\text { Output } \\
\mathrm{L} & =\text { Input tenaga kerja } \\
\mathrm{M} & =\text { Input material } \\
\mathrm{E} & =\text { Input } \text { energi } \\
\mathrm{K} & =\text { Input modal } \\
\mathrm{I} & =\text { Input total } \\
\mathrm{n} & =\text { Tahun yang diukur } \\
\mathrm{i} & =\text { Tahun periode dasar }
\end{array}
$$

Output dan input dihitung berdasarkan harga periode dasar selanjutnya diukur lima indeks produktivitas utama yang terdiri dari :
a. $\mathrm{IPL}=\left(\frac{\mathrm{On} / \mathrm{Ln}}{\mathrm{Oi} / \mathrm{Li}}\right)=\left(\frac{\mathrm{PLn}}{\mathrm{PLi}}\right)$
b. $\mathrm{IPM}=\left(\frac{\mathrm{On} / \mathrm{Mn}}{\mathrm{Oi} / \mathrm{Mi}}\right)=\left(\frac{\mathrm{PMn}}{\mathrm{PMi}}\right)$
c. $\mathrm{IPE}=\left(\frac{\mathrm{On} / \mathrm{En}}{\mathrm{Oi} / \mathrm{Ei}}\right)=\left(\frac{\mathrm{PEn}}{\mathrm{PEi}}\right)$
d. $\mathrm{IPK}=\left(\frac{\mathrm{On} / \mathrm{Kn}}{\mathrm{Oi} / \mathrm{Ki}}\right)=\left(\frac{\mathrm{PKn}}{\mathrm{PKi}}\right)$
e. $\quad I P T=\left(\frac{O n / T n}{O i / T i}\right)=\left(\frac{P T n}{P T i}\right)$
Keterangan :
IPL = Indeks produktivitas tenaga kerja
IPM = Indeks produktivitas material
IPE = Indeks produktivitas energi
IPK = Indeks produktivitas modal
IPT $=$ Indeks produktivitas total
PL = Rasio produktivitas tenaga kerja
$\mathrm{PM}=$ Rasio produktivitas material
$\mathrm{PE}=$ Rasio produktivitas energi
$\mathrm{PK}=$ Rasio produktivitas modal
PT = Rasio produktivitas total

\section{Perhitungan Angka Indeks Profitabilitas}

Apabila perhitungan angka indeks menggunakan harga konstan, maka perhitungan indeks profitabilitas dilakukan dengan menggunakan harga-harga yang berlaku.

Angka indeks yang akan digunakan dalam pengukuran profitabilitas ini terdiri dari lima indeks produktivitas utama, namun sebelumnya terlebih dahulu dilakukan pengukuran terhadap enam indeks pendukung yang dapat mendukung dalam analisis selanjutnya, adapun indeks tersebut antara lain (Eka, 2012) :

a. Indeks output $(\mathrm{O})=\frac{\mathrm{On}}{\mathrm{Oi}}$

b. Indeks input tenaga kerja $(\mathrm{L})=\frac{\mathrm{Ln}}{\mathrm{Li}}$

c. Indeks input material $(\mathrm{M})=\frac{\mathrm{Mn}}{\mathrm{Mi}}$

d. Indeks input energi $(\mathrm{E})=\frac{\mathrm{En}}{\mathrm{Ei}}$

e. Indeks input modal $(\mathrm{K})=\frac{\mathrm{Kn}}{\mathrm{Ki}}$

f. Indeks input total $(\mathrm{I})=\frac{\text { In }}{\text { Ii }}$
Keterangan :
$\mathrm{O}=$ Output
$\mathrm{L} \quad=$ Input tenaga kerja
$\mathrm{M}=$ Input material
$\mathrm{E} \quad=$ Input energi 
$\mathrm{K} \quad=$ Input modal

I $\quad=$ Input total

$\mathrm{n} \quad=$ Tahun yang diukur

$\mathrm{i} \quad=$ Tahun periode dasar

Output dan input dihitung berdasarkan harga-harga yang berlaku tiap periodenya. Selanjutnya diukur lima indeks profitabilitas untuk msaing-masing input yang digunakan yang terdiri dari (Eka, 2012) :

a. Indeks profitabilitas tenaga kerja (IPFL)

$\mathrm{IPFL}=\left(\frac{\text { Indeks } \text { output }}{\text { Indeks input tenaga kerja }}\right) \times 100$

b. Indeks profitabilitas material (IPFM)

IPFM $=\left(\frac{\text { Indeks output }}{\text { Indeks input material }}\right) \times 100$

c. Indeks profitabilitas energi (IPFE)

$\mathrm{IPFE}=\left(\frac{\text { Indeks output }}{\text { Indeks input } \text { energi }}\right) \times 100$

d. Indeks profitabilitas modal (IPFK)

IPFK $=\left(\frac{\text { Indeks output }}{\text { Indeks input } \text { modal }}\right) \times 100$

e. Indeks profitabilitas total (IPFT)

$\mathrm{IPFT}=\left(\frac{\text { Indeks output }}{\text { Indeks input total }}\right) \times 100$

\section{Perhitungan Angka Indeks Perbaikan Harga}

Indeks perbaikan harga (IPH) pada dasarnya merupakan rasio antara indeks profitabilitas (IPF) dengan indeks produktivitas (IP). Dengan demikian perhitungan indeks perbaikan harga dilakukan sebagai berikut :

a. Indeks perbaikan harga untuk input tenaga kerja (IPHL)

$\mathrm{IPHL}=\left(\frac{\mathrm{IPFL}}{\mathrm{IPL}}\right)$

b. Indeks perbaikan harga untuk input material (IPHM)

$\mathrm{IPHM}=\left(\frac{\text { IPFM }}{\text { IPM }}\right)$

c. Indeks perbaikan harga untuk input energi (IPHE)

$\mathrm{IPHE}=\left(\frac{\mathrm{IPFE}}{\mathrm{IPE}}\right)$

d. Indeks perbaikan harga untuk input modal (IPHK)

$\mathrm{IPHK}=\left(\frac{\mathrm{IPFK}}{\mathrm{IPK}}\right)$

e. Indeks perbaikan harga total (IPHT)

$\mathrm{IPHT}=\left(\frac{\mathrm{IPFT}}{\mathrm{IPT}}\right)$

\section{Metode Penelitian}

Metodologi penelitian menguraikan seluruh kegiatan yang dilaksanakan selama kegiatan penelitian berlangsung yang dimulai dari menentukan suatu permasalahan, pengumpulan data baik melalui buku-buku panduan maupun studi lapangan, melakukan penelitian berdasarkan data yang ada sampai dengan penarikan kesimpulan dari permasalahan yang diteliti.

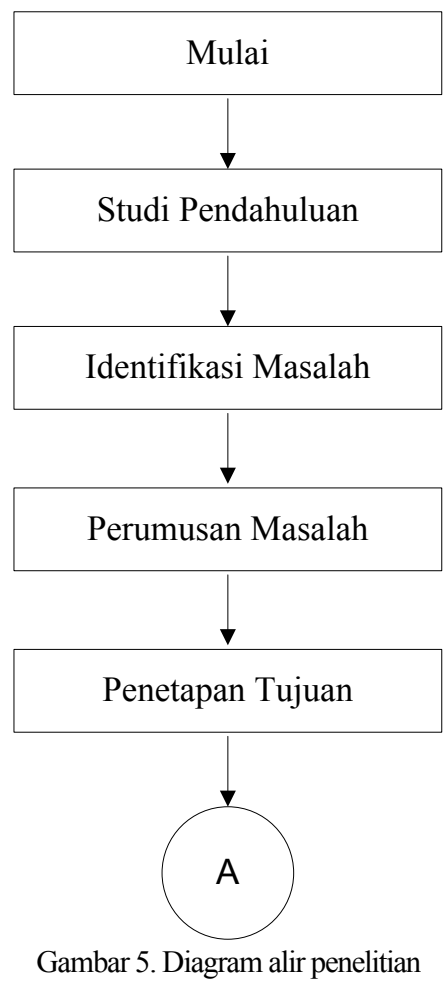




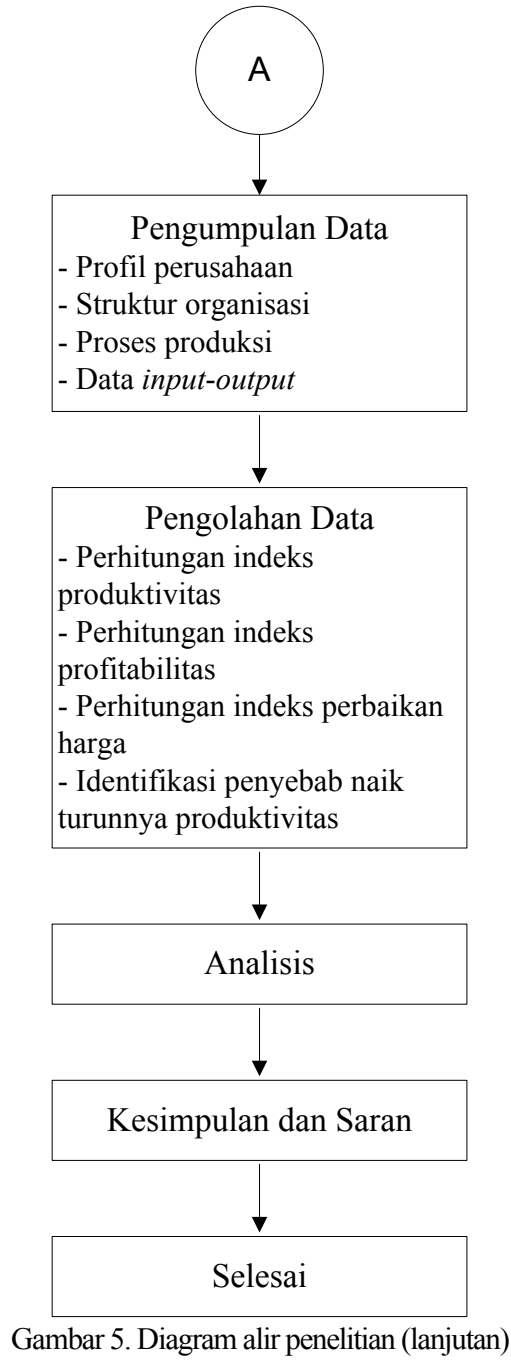

\section{Hasil dan Pembahasan}

Hasil Perhitungan Indeks Produktivitas, Indeks Profitabilitas, dan Indeks Perbaikan Harga untuk Input Total

Tabel 1. Rekapitulasi indeks produktivitas, indeks profitabilitas, dan indeks perbaikan harga untuk input total

\begin{tabular}{lccc}
\hline \multirow{2}{*}{ Bulan } & \multicolumn{3}{c}{ Input Tenaga Kerja } \\
\cline { 2 - 4 } & IP & IPF & IPH \\
\hline Februari & 0.98 & 0.99 & 1.01 \\
Maret & 0.93 & 0.93 & 1 \\
April & 0.97 & 0.98 & 1.01 \\
Mei & 0.97 & 1.03 & 1.06 \\
Juni & 0.93 & 0.93 & 1 \\
Juli & 0.91 & 0.91 & 1 \\
Agustus & 0.95 & 0.95 & 1
\end{tabular}

\begin{tabular}{lccc} 
September & 0.94 & 0.94 & 1 \\
Oktober & 0.93 & 0.93 & 1 \\
November & 0.92 & 0.92 & 1 \\
Desember & 0.87 & 0.89 & 1.03 \\
\hline
\end{tabular}

IP, IPF, dan IPH untuk Input Total Tahun 2015

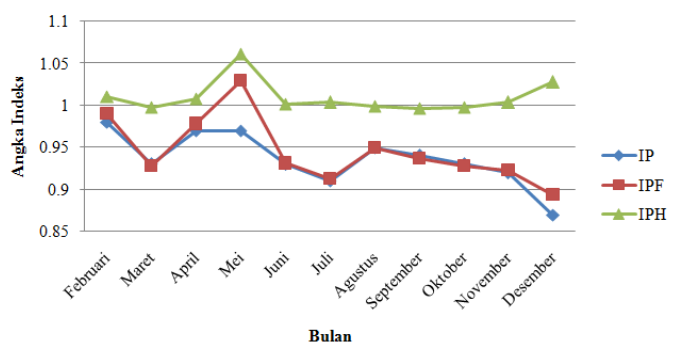

Gambar 4. Grafik perkembangan IP, IPF, dan IPH untuk input total tahun 2015

Berdasarkan perhitungan indeks produktivitas dengan metode APC (American productivity center) dapat dilihat bahwa indeks produktivitas total selama tahun 2015 terus mengalami penurunan, hal ini disebabkan oleh jumlah input - input yang digunakan dalam proses produksi masih jauh lebih tinggi dibandingkan dengan hasil produksi, seperti kenaikan input material (tandan buah segar yang diolah) tidak berbanding lurus dengan CPO (crude palm oil) dan inti yang dihasilkan. Hal ini lah yang kemudian menyebabkan turunnya indeks produktivitas total perusahaan.

Berdasarkan perhitungan indeks profitabilitas untuk input total dapat dilihat bahwa indeks profitabilitas total selama tahun 2015 cenderung turun. Kenaikan indeks profitabilitas hanya terjadi pada bulan Mei sebesar 3\%. Penurunan profitabilitas ini disebabkan oleh jumlah input - input yang digunakan dalam proses produksi seperti kenaikan input material (tandan buah segar yang diolah) masih jauh lebih tinggi dibandingkan dengan hasil produksi, tidak berbanding lurus dengan CPO (crude palm oil) dan inti yang dihasilkan, hal ini diperparah dengan melemahnya harga jual CPO (crude palm oil) dan inti serta naiknya harga solar.

Berdasarkan perhitungan indeks perbaikan harga untuk input total dapat dilihat bahwa indeks perbaikan harga total selama tahun 2015 cenderung stabil. Kenaikan indeks perbaikan harga hanya terjadi pada bulan Februari, April, Mei, dan Desember sebesar $1 \%, 1 \%, 6 \%$, dan 3\%. Kondisi ini dikarenakan indeks perbaikan harga untuk input tertentu yang mengalami penurunan ditutupi dengan indeks perbaikan harga untuk input lainnya yang mengalami peningkatan maupun stabil. 


\section{Identifikasi penyebab naik turunnya produktivitas}

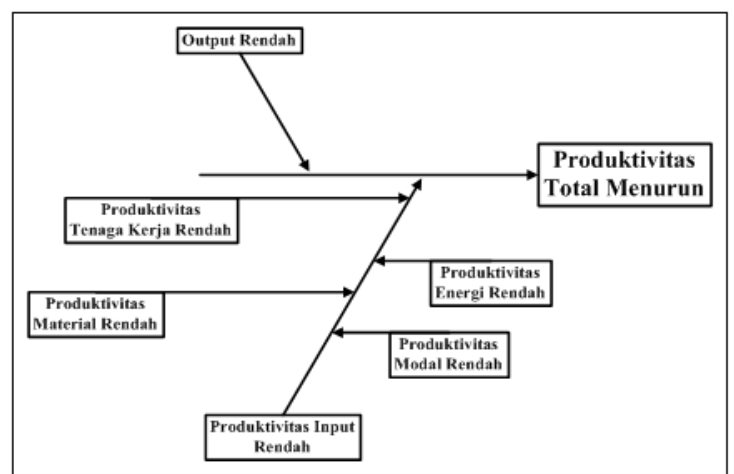

Gambar 6. Diagram sebab akibat penurunan produktivitas total

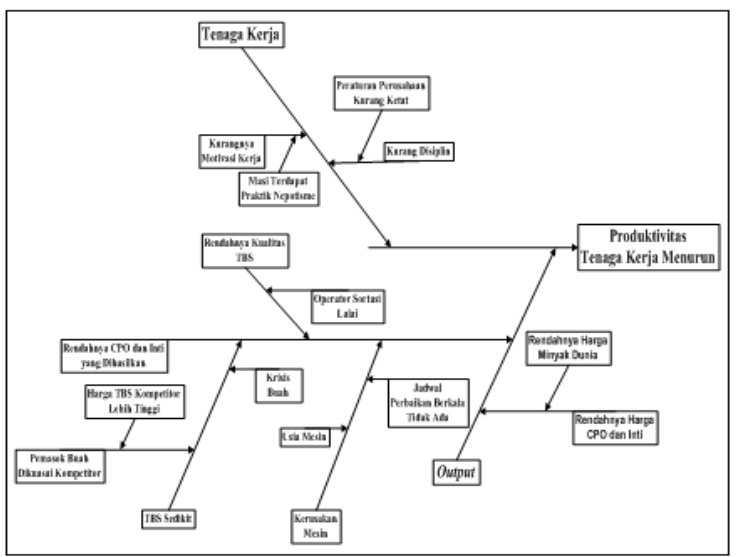

Gambar 7. Diagram sebab akibat penurunan produktivitas tenaga kerja

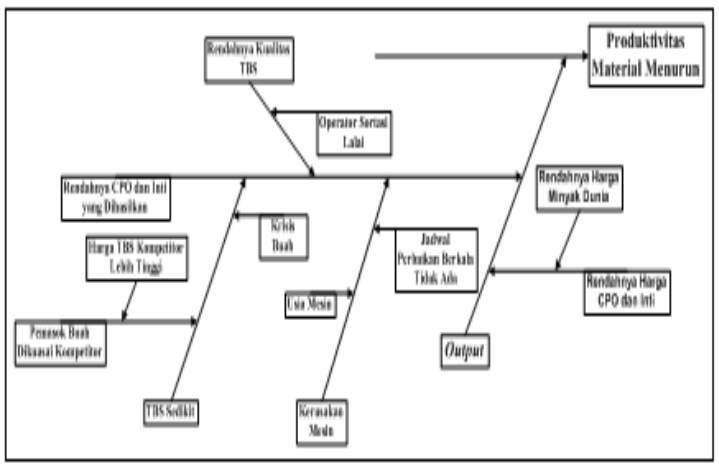

Gambar 8. Diagram sebab akibat penurunan produktivitas material

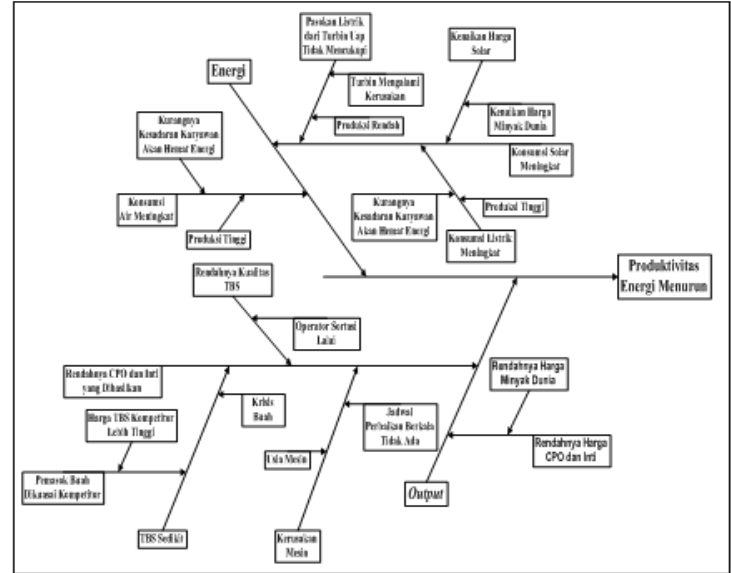

Gambar 9. Diagram sebab akibat penurunan produktivitas energi

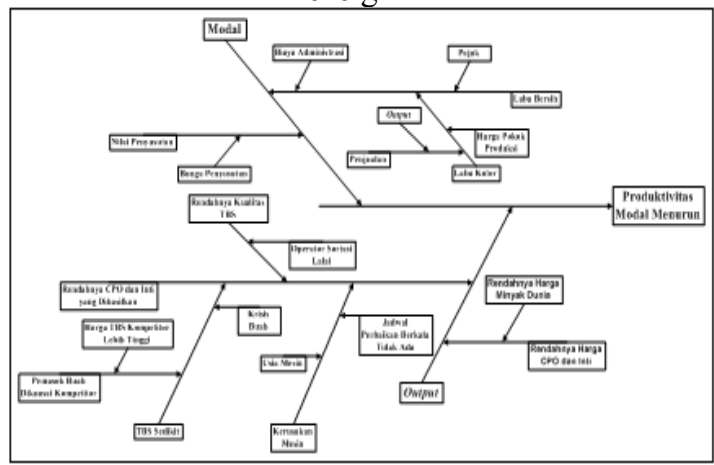

Gambar 10. Diagram sebab akibat penurunan produktivitas modal

\section{Menentukan Strategi Untuk Meningkatkan Produktivitas}

Setelah dilakukan identifikasi penyebab naik turunya produktivitas dengan menggunakan diagram sebab akibat pada bab pengolahan data, maka selanjutnya dilakukan analisa untuk menentukan strategi peningkatan produktivitas dengan menggunakan tree diagram.

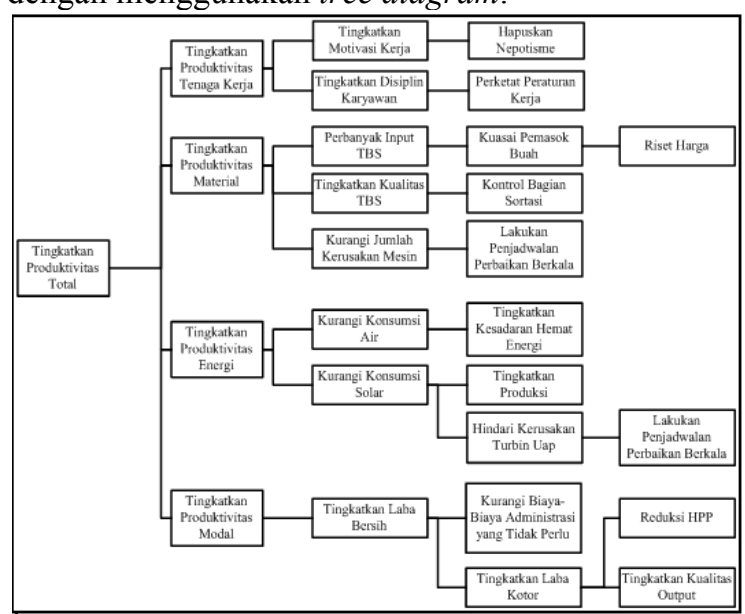

Gambar 11. Tree diagram untuk menentukan strategi peningkatan produktivitas 


\section{Kesimpulan}

Indeks produktivitas total perusahaan selama tahun 2015 mengalami penurunan, hal ini disebabkan oleh jumlah input-input yang digunakan dalam proses produksi masih jauh lebih tinggi dibandingkan dengan jumlah hasil produksi. Sebagai contoh pada input material, TBS (tandan buah segar) yang diolah mengalami peningkatan namun peningkatan jumlah input tersebut tidak berbanding lurus dengan CPO (crude palm oil) dan inti yang dihasilkan.

PT. Perkebunan Nusantara V Sei Galuh belum efektif dalam menjalankan bisnisnya, ini dapat dilihat dari indeks profitabilitas total perusahaan selama tahun 2015 cenderung mengalami penurunan, hal ini menyebabkan perusahaan tidak maksimal dalam menghasilkan laba.

Berdasarkan tree diagram usulan langkahlangkah peningkatan produktivitas yang dapat diberikan antara lain : Mengoptimalkan proses produksi agar peningkatan TBS (tandan buah segar) yang diolah berbanding lurus dan positif terhadap hasil produksi CPO (crude palm oil) dan inti (kernel), melakukan pengawasan yang ketat dalam kegiatan sortir bahan baku TBS (tandan buah segar) sesuai dengan standar kematangan yang bagus, melakukan perhitungan secara tepat mengenai penentuan harga beli TBS (tandan buah segar), hal ini bertujuan untuk menjaga ketersediaan bahan baku agar tidak direbut oleh kompetitor, meningkatkan efektivitas penggunaan mesin-mesin produksi dengan cara melakukan penjadwalan perbaikan berkala untuk mencegah kerusakan mesin-mesin pada saat proses produksi serta efisiensi penggunaan energi, dan melakukan reduksi terhadap biaya-biaya administrasi maupun biaya produksi yang tidak perlu.

\section{Daftar Pustaka}

Agustina, Fitri, Nina Aris Riana. 2011. Analisis Produktivitas Dengan Metode Objective Matrix (OMAX) Di PT.X. Jurnal. Teknik dan Manajemen Industri, 6(2): 150-158.

Avianda, Dea, Yoanita Yuniati, Yuniar. Strategi Peningkatan Produktivitas di Lantai Produksi Menggunakan Metode Objective Matrix (OMAX). Jurnal. Teknik Industri, 1(4): 1-12.

Eka, Yusmalina. 2012. Penerapan Metode American Productivity Center (APC) Dalam Meningkatkan Produktivitas dan Profitabilitas. Skripsi. Fakultas Teknik Universitas Islam Sultan Syarif Kasim Riau. 94 hal.

Eko, Muhammad Harizki. 2009. Analisis Pengukuran Produktivitas Perusahaan
Dengan Menggunakan Metode Marvin E Mundel Di PTPN IV PKS Pabatu, Tebing Tinggi. Skripsi. Fakultas Teknik Universitas Sumatera Utara. 146 hal.

Gaspersz, Vincent. "Manajemen Produktivitas Total". PT. Gramedia Pustaka Utama, Jakarta. 1998.

Ginting, Hendra Poerwanto. 2012. Zona Manajemen.

https://sites.google.com/site/kelolakualitas/ Diagram-Fishbone. diakses pada 24 Juni 2015. 23:25.

Hakim, Afif. 2010. Analisa Efisiensi Dan Produktivitas Dengan Menggunakan Metode Data Envelopment Analysis Dan Malmquist Productivity Index. Skripsi. Fakultas Sains dan Teknologi Universitas Islam Negeri Sunan Kalijaga. 49 hal.

Nasution, Arman Hakim. "Manajemen Industri", ed.1. Yogyakarta: Andi. 2007.

Nopiandi, Dedi. 2012. Pengukuran Produktvitas Untuk Mengidentifikasi Pemborosan Sumberdaya Produksi Menggunakan Metode Objective Matrix (OMAX) PT. XYZ. Skripsi. Fakultas Teknik Universitas Tanjung Pura. 6 hal.

Sinungan, Muchdarsyah. "Produktivitas Apa Dan Bagaimana", ed.2. Jakarta: Bumi Aksara. 2005.

Susanti, Lusi, Dicky Fatrias, Siviana Kalangi. 2008. Pengukuran Produktivitas PTP Nusantara VI Unit Usaha Kayu Aro Dengan Metode Objective Matrix. Jurnal Teknik Industri, 8(1): 17-21.

Sutikno, S. 2010. Sistem Pendukung Keputusan Metode AHP Untuk Pemilihan Siswa Dalam Mengikuti Olimpiade Sains Di Sekolah Menengah Atas. Skripsi. Fakultas Matematika dan Ilmu Pengetahuan Alam Iniversitas Dipenogoro. 10 hal.

Zulkarnaen, NS. 2009. "Manajemen Produktivitas". Mei. 2015. [Online] Available http://maidungleekapay.blogspot.com/2008/07/manajem en-produktivitas.html, diakses $27 \mathrm{Mei}$ 2015, 21:00.

Wignjosoebroto, Sritomo. "Pengantar Teknik dan Manajemen Industri”, Edisi 1. Jakarta: Guna Widya. 2006. 